\title{
Peasant Strategies in the Cotton Regions of Cameroon: Lessons From the Lam Cotton Zone
}

\author{
Anatole DAKA (corresponding author) \\ School of Public Administration, Department of Sociology, Hohai University \\ 8 Focheng West Road, Jiangning District, Nanjing \\ 211100, P.R. China
}

Tel: 86-131-5175-2900 E-mail: d2018@hhu.edu.cn

\begin{abstract}
Yijie WANG
School of Public Administration, Department of Sociology, Hohai University

8 Focheng West Road, Jiangning District, Nanjing

211100, P.R. China

E-mail:wangyj_73@163.com

\section{Liang HU}

School of Public Administration, Department of Sociology, Hohai University

8 Focheng West Road, Jiangning District, Nanjing

211100, P.R. China

E-mail: hlt8179hu@gmail.com
\end{abstract}

Received: October 10, 2019 Accepted: November 5, 2019 Published: November 11, 2019

doi:10.5296/ijld.v9i4.15801ＵRL: https://doi.org/10.5296/ijld.v9i4.15801

\begin{abstract}
Faced with increasingly drastic conditions, Lam cotton farmers are using indigenous knowledge to develop alternative strategies. The objective of this paper is to analyze the supervision issue of cotton farmers in north Cameroon. Ethno methodology and strategic analysis are the theories used to explain the practical knowledge and strategies employed by
\end{abstract}


the cotton farmers. Based on the collected results, it's noticed that the training is imposed by the SODECOTON (cotton development society) with the aim of maintaining its domination over cotton farmers, thereby conveying capitalistic logic and impoverishing peasants. The failure of the above-mentioned training technique has led to new emerging strategies conceived and implemented by the peasants.

Keywords: Indigenous knowledge, Training, peasant strategies, SODECOTON, cotton farmers

\section{Introduction}

Since its forced introduction to North of Cameroon in the 20th century (1950) by the French Textile Development Company (Compagnie Française pour le Développement de Textile-CFDT), cotton as a commercial crop has been at the origin of various social conflicts between cotton farmers and agents framing on the one hand and between the cotton farmers themselves on the other; plunging them into deep concern (Daka, 2018, p. 12). The creation of cotton development society (Société du Développement du Coton-SODECOTON) in 1974 came as a breath of fresh air to relieve farmers. The latter then proceeded with the reform of the cotton sector by involving cotton culture in the management of the sector. Farmers' organizations, cooperatives and farmers' associations have been set up by SODECOTON to solve this problem (Kossoumna, 2014, p. 25). Several framing techniques were introduced in order to better control the North-Cameroon peasantry. Research has also been carried out, notably in the context of the IRAD-SODECOTON cooperation.

Despite all these geographical and human assets, the colossal work of research and the reform of management policies, the fact remains that the peasant's problems remain unresolved and the supervision rather generates ideological, economic, social and political problems. From then on, the peasant dynamics emerged.

\section{Methodology}

On the theoretical level, we used strategic analysis to better understand the topic of our research. The choice of the strategic analysis in this study was based on the idea that: the supervision of cotton producers by SODECOTON and the strategies of Lam farmers to circumvent the impacts of this framework are the leitmotif of sociological analysis in the context of this work.

In this study, the strategies of Lam cotton producers to circumvent the SODECOTON drain are "winning strategies" in Crozier's sense (Crozier \& Friedberg, 1997).

The strategies refer to the ingenious reactions of Lam cotton producers to the constraints of SODECOTON. And therefore, the way in which the latter exerts its domination over peasants refers to what the strategic analysis calls "the constraints of collective action" (Crozier \& Friedberg, 1997, p. 90). It is from these alternative strategies that Lam farmers make the social structures of their communities observable and analyzable. Thus, considering the reactions of Lam cotton producers as a choice through which the actor seizes the opportunities available to him in the context of the constraints that are his own constraints that he may eventually exceed 


\section{Macrothink}

International Journal of Learning and Development

ISSN 2164-4063

2019, Vol. 9, No. 4

but at a cost p. 71)., this study is consistent with the logic of strategic analysis. In this sense, peasant strategies are analyzed as the result of a conscious and deliberate act by social actors (Lam cotton producers). Thus, the meaning that Lam cotton producers give to their strategies allows us to understand the social world in which these strategies are developed.

In addition, for the collection of field data, we used direct maintenance, indirect administration questionnaire, observation and documentary research. We chose a sample of one hundred and thirty-five cotton farmers. The survey involved 28 women and 107 men, representing $38 \%$ and $62 \%$ respectively of the 09 quarters in the village of Lam. These include Koukoi, Digar, Dohong Lam, Dohong Douva, Dedagguela, kissoyomo, Karbaza, Kapta Brousse, Gabla. In each quarter, about $25-40 \%$ was also given to women.

\section{Synoptic Presentation of the Lam Village}

Located in Mayo-Louti division in the cotton basin of North-Cameroon, Lam village has a huge agricultural potential. Featuring a type of Sudano-Sahelian climate with a rainfall of over 900 cubic millimeters per year, this village has a grassy vegetation dotted with tall trees. Lam is populated since the 17th century. Indeed, the Guidars in their quest for habitable and cultivable land were attracted by this village with fairly fertile land and whose imposing mountain could be used as shelter in case of attack. Lam extends between $10^{\circ} 14$ north latitude and $14^{\circ} 74$ east longitude. Its average altitude is about $400 \mathrm{~m}$. The map below gives us a synoptic presentation of this village.

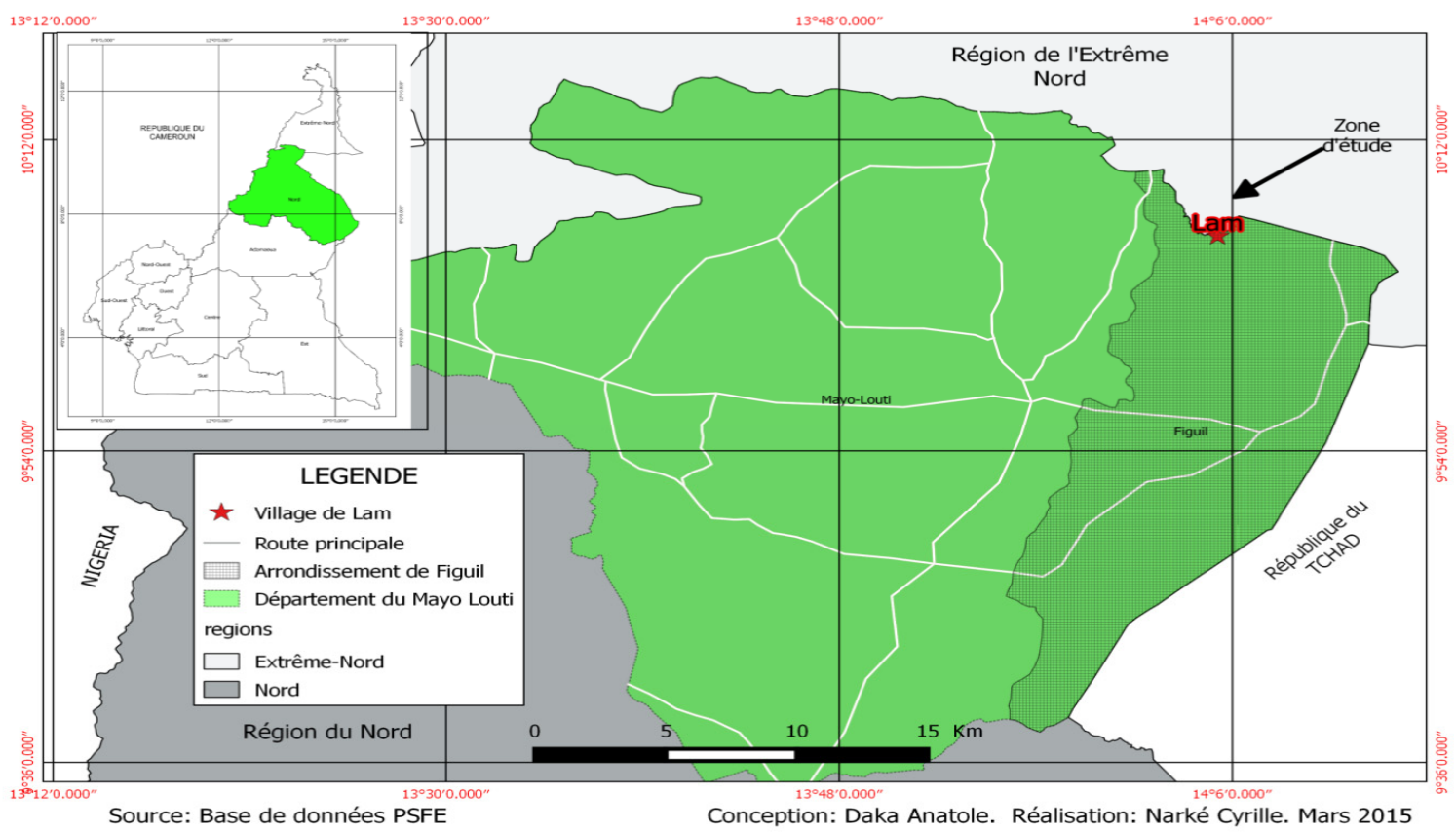

Figure 1. Location map of the study area

\section{The Framing Techniques of Cotton Farmers in North Cameroon}

The supervision of cotton farmers in North Cameroon is based on a set of techniques, 
principles and practices ranging from the organization of cotton farmers to the purchase of seed cotton. We will emphasize here not only on how to make a synoptic but also on critical presentation of these techniques.

\subsection{Grouping Farmers Into Solidarity Bond Circles}

Concerning the viability of the input credit and repayment of credits within groups of producers of too large size, SODECOTON has set up the Solidarity Bond Circles.

\subsubsection{The Conditions of Membership in a Solidarity Bond Circle}

In order to benefit from the input credit, the producer has the obligation to join a particular solidarity bond circle. The accession of a planter to this circle follows a careful examination at the level of the Group of Common Interest (GCI) and the solidarity bond circle concerned. This review is related to the future member's production capacity and conduct. After this review, he may or may not have the authorization to join. The principle of solidarity bonding applies at two levels, within each solidarity bond circle, and within each GCI (Enam, Klassou, Folefack, Kouebou, \& Fok, 2008, p. 6).

\subsubsection{How the Solidarity Bond Circle Works}

Solidarity bonding as it is today in North Cameroon benefits cotton farmers little (Legile, 2002, p. 1). Practically, failing members, for unjustifiable reasons, may be excluded from their solidarity bond circle. The exclusion process may also apply to solidarity bond circles at the GCI level. In the latter case, it is a collective exclusion that applies. This is called 'remediation'. In addition to the solidarity bond, there is another technique whose operation remains misunderstood and even incomprehensible by cotton farmers; it is about the marketing of cotton itself.

\subsection{Cotton Marketing}

Cotton marketing has changed in a few ways in recent years (Vall et al., 2002, p. 130). This includes the classification of seed cotton, delayed purchase, evacuation and delayed payment of the price to the producer (Djamen, \& al., 2003/ p. 43). The current process of marketing seed cotton places producers at risk, such as the delay of several months in the purchase of cotton, most often caused by the failure of the cotton company itself. Combined with the absence of an insurance scheme, the solidarity bond is reduced to a low-performing tool for collecting input credits and is the source of conflict within the GCI. The marketing of seed cotton is also plagued by a multiplicity of illegal practices such as the classification of seed cotton.

\subsection{The Classification of Seed Cotton}

The classification of seed cotton is a method adopted with the aim of improving the quality of cotton. For SODECOTON (2003), it encourages farmers to harvest with great care in order to present it clean cotton; that is, the one qualifying as the first choice. There have been many failures in the cotton classification. First, it should be noted that the corruption of the ranking officers in the markets impose a low-end classification and finally the delay in the collection of cotton by SODECOTON contributes to further smearing it; because the latter is exposed to the 
open air for many months waiting for the SODECOTON purchasing team. Moreover, even if this cotton is bought, we also note the delay of evacuation. Indeed, the cotton purchased spends several months on the market to the full responsibility of cotton farmers.

\subsection{Delay in Collection and Evacuation: The Risks}

Collecting here is the system of buying cotton on credit by SODECOTON and the word evacuation refers to the transport of that cotton sold in the seeding mills. In recent years, the delay in the collection and evacuation of cotton has become recurrent in North Cameroon. This phenomenon is even getting worse. From four to five months in the early 2000 s, today, the collection is more than ten months behind, as is the case for the 2014-2015 campaign ( $\mathrm{S}$. Haman, personal communication, August 15, 2015). And this poses enormous risks for cotton farmers. Indeed, the more time cotton spends in the open air in the sun, the more it gets dirty and loses its weight. Added to this problem is the delays in paying producers, which is constantly increasing.

These situations have a negative impact on farmers. First of all, when the cotton is not quickly sold, it is at the risk and peril of the cotton famers because, fire or rain could damage it at any time. In addition, the delay in collection also presents the risk of theft. Indeed, cotton famers most often face situations of theft of the seed cotton. Finally, it should also be stressed that the rapid or timely non-flow of cotton-seed penalizes the farmer in the sense that he will always be waiting and could not collect his due at the time to buy cereals, and other foodstuffs to cope with the welding period; because in North Cameroon many farmers grow cotton in order to get cash.

\subsection{Payment Delay}

The average delay in collecting prices paid to planters was two months in the early 2000s. It has already reached almost a year in the 2014-2015 agricultural season. According to SODECOTON officials, it is mainly caused by the state of the treasury and the financing of its accounting exercises, which depends on the global market conditions.

Who benefits from the supervision of cotton farmers in North Cameroon? This is the question that can be asked after this study of framing techniques. In response, we analyzed the social and economic areas of cotton farmers in order to better understand the impact of supervision on their living conditions.

\section{The Framing of Cotton Farmers in North Cameroon: What Impacts?}

The techniques of framing cotton farmers have produced perverse effects (We hear the term perverse effects here in the sense of R. Boudon. Read usefully on this subject his book entitled: Effets pervers et ordre social, Paris, PUF, 1977) in the social organization of the populations of Lam. On the social level, the perverse effects of these techniques create social conflicts; similarly, soaring input prices significantly increase the number of unpaid debts in solidarity bond circles. 


\section{MInstitute Macrothink}

\subsection{The Phenomenon of Unpaid}

In recent years, a new word has entered the vocabulary of Lam cotton famers; it's the term "unpaid". It refers to a planter who has not been able to refund all the packages of his inputs to SODECOTON but who still owes the company. Clearly, changes in input prices in recent years have been at the root of this phenomenon. The recovery of the credit being made on sale by the National Confederation of Cotton Producers of Cameroon (NCCPC) or by the managers in the markets, the latter level the amount equivalent to the credit and the rest of the sales income goes to the producer. Difficulties are reported in cases where the production balance is negative.

Deficit farmers are forced to pay costs more than their debt; some even go so far as to withdraw their fund, or even incur debts to repay to SODECOTON. Others, on the other hand, sell their small livestock to the highest bidder to regularize their situation (F. Tizi, personal communication, August 14,2014). The pawning of the fields, the early marriage of girls are all alternatives developed by cotton farmers (Havard \& Abakar, 2002, p.10).

The unpaid situation not only causes conflicts within the village but also encloses and keeps the peasant in a vicious circle. The results of our field surveys conducted last August on this phenomenon are illustrative. Of a sample of 135 surveyed, 115 were found to be unpaid. That's $85.19 \%$ of unpaid planters. The table above is the result of this survey.

Table 1. The summary of unpaid debts in Lam

\begin{tabular}{lllc}
\hline Module & Unpaid & Not Unpaid & Total \\
\hline Number of planters surveyed & 115 & 20 & 135 \\
Percentage (\%) & 85.19 & 14.81 & 100 \\
\hline
\end{tabular}

Source: Field Survey.

Reading this table shows us that almost all cotton farmers are indebted to SODECOTON. In reality, it is difficult for farmers to pay their debts through simple cotton farming. Other alternatives come to the rescue of these unpaid bills as we have shown. It should also be noted that, in view of the above, SODECOTON is transforming the cotton farmer's framework into a market for plant protection products and inputs. It is therefore losing its role as a rural development company to become a commercial company whose main quasi-exclusive objective is to make as much profit as possible.

It should be remembered that this phenomenon of peasant insolvency most often leads to conflicts within the village. 


\subsection{Social Conflict}

SODECOTON's method of recovering input debts creates social conflicts. For the farmer in good standing, that is, the one who paid his credit debts within the period of his credit, it is unbearable that one takes his debt to pay the debt of another peasant, a member of the same solidarity bond circle. The materialization of conflicts between peasants is usually only the overflow of the tensions inherent in the management of members' debt within a solidarity bond circle. The following table describes the consequences of the phenomenon of unpaid debt in Lam.

Table 2. How input credits are recovered and cotton farmer's reactions

\begin{tabular}{lllll}
\hline $\begin{array}{l}\text { Total sample } \\
\text { size }\end{array}$ & Mode & Fight & Amicably & $\begin{array}{l}\text { No } \\
\text { unpaid }\end{array}$ \\
\hline & $\begin{array}{l}\text { Levy on all members of the solidarity } \\
\text { bond circle }\end{array}$ & 106 & 01 & 00 \\
$\mathbf{1 3 5}$ & Confiscation of individual property & 01 & 07 & 00 \\
& Levy at pay time & 00 & 00 & 20 \\
\hline
\end{tabular}

Source : Field Survey.

It follows from our analysis that the supervision of cotton farmers and more precisely solidarity bond circles create more than $92 \%$ of social conflicts in Lam. In view of the above, it appears that the supervision of cotton famers has increased the number of unpaid planters in Lam to more than $85 \%$. And the method of recovery of the package set up in recent years, based on solidarity bond circles for its part is a source of conflict.

In addition, we have used economics to better understand the impact of cotton farmer's supervision on Lam planters.

\subsection{The Decrease in the Number of Planters: The Main Cause of the Decline in Productivity?}

In recent years, the number of producers has declined within GCIs.

Indeed, this decrease is caused by the difficulty of accessing credits and means of production. The withdrawal of farmers from cotton cultivation (by total abandonment or reduction of areas) is recurrent in North Cameroon. Other factors are equally at the root of this phenomenon. These are, on the one hand, low incomes from the sale of cotton, usually below the invested capital, and on the other hand, unpaid debts that appear at different levels; both at the individual level and at the GCI level. 


\section{Macrothink Institute ${ }^{\text {TM }}$}

Clearly, the decline in the number of planters does not solely explain the decline in productivity. There may be a decrease in productivity without necessarily decreasing the number of planters. Similarly, it may also have a decline in productivity that is not directly related to both the decrease in the number of planters and the decrease in the area under cultivation. One can theoretically have the same size and the same area and produce in a decreasing way. The use of agricultural inputs may be the cause.

However, without excluding other possibilities, we rely on the most plausible hypothesis which says that the decline in the number of planters has resulted in a concomitant decline in productivity in the Lam context. The 2005/2006 agricultural season, which saw the withdrawal of some farmers from the cotton sector, is dominated by a decline in productivity felt even to the level of GCI (B. Lawan, personal communication, August 10, 2014). At the level of solidarity bond circles, the consequence is the withdrawal of many of the members.

The decline in income of cotton famers

The income of cotton farmers, although modest, has fallen drastically in recent years. In Lam, the problem of declining income arises more acutely. To achieve this, we have sorted in our sample all the planters who have done at least twenty years in cotton cultivation. The number of these in our sample amounts to 27 male and female planters. Then we assessed their income during those years that they spent on that culture. The result is very surprising. The data is recorded in the table below.

Table 3. Income Statements for Farmers with at Least 20 Years of Cotton Growing

\begin{tabular}{lll}
\hline Evolution of prices & Number of planters & Percentage (\%) \\
\hline Diminution & 21 & 77.78 \\
Stability & 4 & 14.81 \\
Growth/augmentation & 1 & 3.7 \\
Abstention & 1 & 3.7 \\
Total & 27 & 100 \\
\hline
\end{tabular}

Source: Field Survey.

This table reveals that in Lam, the supervision of cotton farmers has only contributed to worsening the living conditions of cotton producers. To make our data more explicit, we opted for representation using a diagram that better highlights these percentages. It gives us a clearer picture of how the phenomenon of declining income has increased in Lam. 


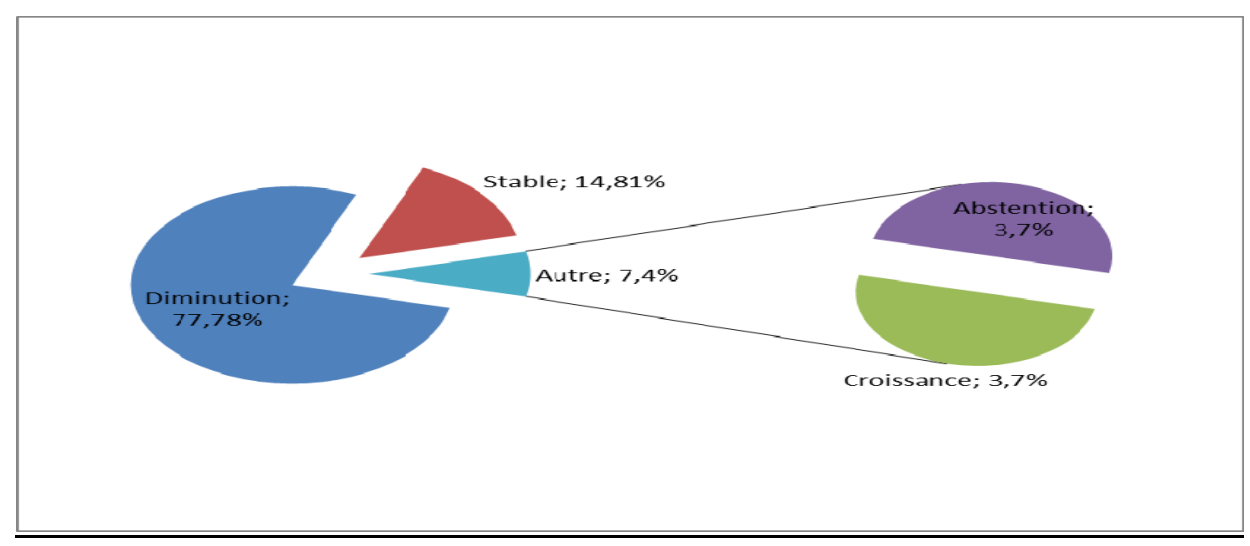

Source: Field Survey

Figure 2. The decline in the incomes of Lam cotton farmers as a result of the new forms of supervision

This figure shows us the decline in the incomes of cotton farmers in Lam related to the methods of supervision. Indeed, over a period of 20 years, we found that more than $77 \%$ of Cotton farmers in Lam saw their incomes fall; $14.81 \%$ of producers stagnated in their earnings, and only $3.7 \%$ experienced a slight change during this period.

The framework, through which the reduction of prices paid to producers, the increase in input prices and many other strategies have negatively influenced the living conditions of the people of Lam. Through our analysis, we found that the incomes of the planters, which at first, it is true, was only modest, has sunk further. Some authors even believe that the current crisis of cotton cultivation in North Cameroon is an indication of a framing failure (Havard \& Djamen, 2010, p. 15). To do this, they recommend that agricultural development actors move from prescriptive to producer support.

Technically, cotton cultivation poses a real threat to the weakening of agrarian society as a whole. The peasant had three reasons for refusing cotton: he gave an over-work by coming into direct competition with food crops, he destroyed the soil and yielded nothing financially (Magnant, 1986, p. 233). In short, in view of this situation, the peasant could not gain anything from this culture. We are witnessing the impoverishment of cotton farmers. Faced with this impoverishment, they develop strategies of adaptation (Kossoumna Liba'a, \& Havard, 2006, p.78).

\section{Cotton farmers face SODECOTON: essay on peasant strategies in north Cameroon}

\subsection{Diversion of Inputs}

In Lam, the phenomenon of diversion of inputs is intense (Oumarou et al., 2017, p.58). Farmers have been seen to enroll in SODECOTON solely for the unspoken purpose of selling inputs or using them in food fields. The latter generally refer to the fertilizers NPK "latia" local name which refers to a very early variety of peanuts and whose sale allows farmers to satisfy several needs during the welding period. For them, NPK fertilizers are a source of income especially in 


\section{Macrothink

the time of welding; that is, the month of August when inputs are distributed. For farmers, there are a number of circumstances that contribute to the fact that they sell or divert inputs for food crops. This includes the increase in input prices that makes them believe that even if they use chemical fertilizers, they will never be able to pay for the package, so they would have to sell it. The other reasons are the lower price to the producer and the neglect of their grievances by SODECOTON. It was these reasons that led them in 2011 to sell cotton in Nigeria.

\subsection{Parallel Sale of Seed Cotton}

In particular, during the 2011 campaign, there was a more assertive opposition from individual producers to the SODECOTON system with refusals to sell, and the extent of smuggling and cotton leakage in neighbouring Nigeria.

The year 2011 marked the history of Cameroonian cotton with the flight of cotton to Nigeria. According to the words conveyed at the 2011 seminar (Garoua, March 2011) the phenomenon stems from a sharp rise in the price of cotton fiber on the world market from December 2010. Nearly 26,000 tons of seed cotton were sold to Nigerian operators' intermediaries by about 37,000 producers at a better price than SODECOTON (Folefack, Bakwowi, \& Kpade, 2014, p. 14). The existence of a more promoter market in Nigeria reinforces and sustains the development of this informal marketing circuit.

In Guider, the city town of the division where our research ground is located, we were interested in this phenomenon, which today constitutes a crucial strategy to respond to the puncture strategies that framing conveys.

Indeed, out of 135 cotton producers surveyed in Lam, and despite the resistance of the latter to give us the information because of the repression of SODECOTON, 28 respondents admitted to having sold cotton to Nigeria in 2011. The following table gives us a general overview of this phenomenon in Lam.

Table 4. Selling Cotton to Nigeria

\begin{tabular}{llll}
\hline Sex & Total staff & Cotton seller in Nigeria & Percentage \\
\hline Woman & 28 & 2 & 2.70 \\
Man & 107 & 26 & 35.10 \\
Total & 135 & 28 & $37.80 \%$ \\
\hline
\end{tabular}

Source: Field Survey.

It is therefore apparent from this table that despite all the repressions, the measures taken by SODECOTON and the mobilization of the police, more than $37 \%$ of the cotton farmers of Lam sold their cotton to Nigeria during the 2010-2011 campaign. This reality is a visible expression of the fact that cotton farmers seek at all costs to get rid of the challenges of framing. Today, 
cross-border insecurity linked to the abuses of the terrorist group Boko Haram has severely limited this phenomenon.

The peasant response to the impacts of framing has not only manifested itself in the diversion of inputs and the parallel sale of seed cotton, but also by many other strategies.

\subsection{The Use of Organic Manure as an Alternative to Chemical Fertilizer}

Made up of animal and plant manure, the manufacture of organic fertilizer is part of the local knowledge of the populations of Lam. The development of local knowledge is often generated by "farmers' goals and constraints" (Farrington \& Adrienne, 1990, p. 60). The new social conditions created by the current supervision of cotton farmers require them to adjust their behavior. These depend on the nature of the new conditions mentioned (Faure, 2005, p. 10). As such, "the stronger is the coercion, the more the popular imagination invents tactics and survival techniques (...)" (Ela, 1990, p. 73).

Organic manure as a technical process that aims at fertilizing and restoring soil fertility is part of what is called a "peasant technology" derived from the local knowledge of the soil that is that of the Lam plain (Hochet \& N'gar-Aliba, 1995, p. 164). It is the consequence, better the corrective strategy of her above who has suffered a stinging failure. With this in mind, it can be considered a "survival strategy," referring to the model of Guimapi (1965). As such, organic manure is not a fortuitous technology, it is the emanation of a strategic calculation obeying precise production and use mechanisms.

The use of chemical fertilizers prior to the framing of cotton farmers has not altered the local knowledge that is the production of organic manure in Lam.

Despite its usefulness, the fertilizer will be substituted by the restitution or exit of the rut of local knowledge.

In Lam, organic manure is produced from household waste, ash from fireplaces, thatch derived from old roofs, the dropping of small domestic ruminants... It must be noted that, before the negative effects of the framing, this household waste was mostly crammed into one place not far from the houses. It was only after suffering the consequences of rising input prices that led to unpaid labor and social conflicts that Lam farmers began to turn waste into organic manure.

The intensive use of organic manure in recent years by Lam farmers is not without consequences for the environment and living conditions of the people who live there. Organic manure has consequences. Indeed, it is clear from our field surveys that about $40 \%$ of our respondents who started the use of organic manure some years ago have noticed a remarkable improvement in their production.

\section{References}

Crozier, M., \& Friedberg, E. (1977). L'acteur et le système. Les contraintes de l'action collective. Paris: Seuil.

Daka, A. (2018). Filière cotonnière et dynamiques paysannes au Nord-Cameroun. Esquisse d'une sociologie du coton partant de l'expérience des coton-culteurs de Lam. Saarbrucken: 


\section{Macrothink}

Éditions universitaires européennes.

Djamen Nana, P., Djonnéwa, A., Havard, M., \& Legile, A. (2003). Former et conseiller les agriculteurs du Nord-Cameroun pour renforcer leurs capacités de prise de décision. Cahiers Agricultures, 12(4), 241-245.

Ela, J. M. (1990). Quand l'Etat pénètre en brousse...les ripostes paysannes à la crise. Paris: L'Harmattan.

Enam, J., Klassou c., Folefack D., Kouebou C., \& Fok M. (2008, Mai, 13-17). Processus associatif chancelant au Cameroun: dégât collatéral des ajustements de politique cotonnière?. ISSCRI International Conference "Rationales and evolutions of cotton policies". Montpellier: France. https://agritrop.cirad.fr/546400

Farrington, J., \& Adrienne, M. (1990). La participation des agriculteurs dans la recherche agricole: concepts et pratiques. Londres: Overseas development Institute.

Faure, G. (2005). Valorisation agricole des milieux de savanes en Afrique de l'Ouest : des résultats contrastés. Les Cahiers d'outre-mer, 229, 5-24. http://journals.openedition.org/com/262; DOI : 10.4000/ com.262

Folefac, D. P., Bakwowi, J. N., \& Kpade, P. C. (2014). La crise de la filière cotonnière et sécurité alimentaire au nord Cameroun. Journal of Applied Biosciences, 75, 6221-623. http://dx.doi.org/10.4314/jab.v75i1.8

Guimapi, C. (1995). Les réactions de survie des femmes à Yaoundé. Yaoundé: Cahiers d'OCISCA, 16.

Havard, M., \& Abakar, O. (2002). Caractéristiques et performances des exploitations agricoles des terroirs de référence du PRASAC au Cameroun. Garoua (Cameroun): Irad-PRASAC.

Havard, M., \& Djamen Nana, P. (2010). Réforme de l'accompagnement des producteurs au Nord-Cameroun : Leçons d'un partenariat entre Recherche - Développement - Producteurs. Agridape, 26(3), 14-16. http://www.agriculturesnetwork.org/magazines/west-africa/partenariats-apprentissage

Hochet, A. M., \& N'gar-Aliba. (1995). Développement rural et méthodes participatives en Afrique. Paris: l'Harmattan.

Kossoumna Liba'a, N. (2014). Crise de la filière coton au Cameroun: Fondements et stratégie d'adaptation des acteurs. Yaoundé: clé.

Kossoumna Liba'a, N., \& Havard, M. (2006). Mutations de la filière cotonnière dans les provinces septentrionales du Cameroun : perception et stratégies paysannes, Cahiers de géographie du Québec, 50(139), 65-82. https://doi.org/10.7202/012935ar

Legile, A. (2002). Groupements de producteurs cotonniers du Nord-Cameroun : favoriser la responsabilisation collective. In J. Y. Jamin, \& L. S. Boukar (Ed.), Savanes africaines : des espaces en mutation, des acteurs face à de nouveaux défis. Garoua: Actes du colloque. 
Magnant, P. (1986). La terre Sara, terre tchadienne. Paris: l'Harmattan.

Oumarou, Y., Saidou, A. A., Madi, A., Watang Zieba, F., \& Fokou Yemata, O. (2017). Perception paysanne des perturbations pluviométriques et stratégies d'adaptation dans les systèmes de culture à sorgho repiqué en zone soudano-sahélienne du Cameroun. Afrique Science, 13(4), 50-65. Retrieved from http://www.afriquescience.info

SODECOTON. (2003). Rapports semestriels campagnes agricoles. 1980/1981 à 2002/2003. Garoua (Cameroun): Direction de production agricole.

Vall, E., Dongmo, A. L., Abakar, O., \& Meyer, C. (2002). La traction animale dans le nouveau contexte des savanes cotonnières du Tchad, du Cameroun et de la République centrafricaine I. Diffusion de la traction animale et sa place dans les exploitations. Revue d'élevage et de médecine vétérinaire des pays tropicaux, 55(2), 117-128. https://doi.org/10.19182/remvt.9832

\section{Copyright Disclaimer}

Copyright for this article is retained by the author(s), with first publication rights granted to the journal.

This is an open-access article distributed under the terms and conditions of the Creative Commons Attribution license (http://creativecommons.org/licenses/by/4.0/). 